\title{
Kuinka lukea klassikoita?
}

Kiinnostava kirjallisuus ja kirjallisuudentutkimus syntyvät usein liikkeestä keskustan ja marginaalin välillä. Toisinaan on vaikea sanoa, mikä on keskustaa, mikä marginaalia. Tämän voi havaita, kun selailee Avain-lehden vuoden 2018 aiheita. Alkuvuoden numeroissa tilaa ovat saaneet perinteisesti kirjallisuudentutkimuksessa marginaalisiksi mielletyt mediatekstit, sarjakuva ja kokeellinen kirjallisuus - lajit, jotka haastavat meitä pohtimaan kirjallisuuden ja muiden tekstien rajapintaa ja keskenään risteäviä vaikuttamisen tapoja.

Avaimen numero 4/2018 sukeltaa kirjallisuuden perinteisempään ytimeen, romaaneihin, runoihin ja lukijan rooliin. Näihin etsitään lehden kirjoituksissa uusia tulokulmia. Numeron avaavassa, Kati Launiksen ja työryhmän artikkelissa "Mitä naiset lukevat?" selvitetään "big datan" ja digitaalisten tutkimusmenetelmien mahdollisuuksia lukijatutkimuksessa. Työryhmän data-analyysi on armoton ainakin klassikoille: Kivet ja Runebergit osuvat harvoin edes keskiikäisten kulttuurin suurkuluttajien kirjakoriin.

Klassikoihin tarttuminen kuitenkin kannattaa. Lehden muissa artikkeleissa luetaan uudelleen tunnettuja kotimaisia, mutta liian usein hyllyyn jääviä teoksia. Kasimir Sandbacka nostaa esiin Tove Janssonin Muumi-tuotannon varjoon jääneet novellit. Hän pohtii artikkelissaan "Myöhäismoderni melankolia Tove Janssonin novelleissa 'Aikakäsite' ja 'Lokomotiivi"' ajan kokemiseen ja tuntemiseen liittyviä kysymyksiä. Mikko Turunen kokeilee artikkelissaan "Maiseman poetiikkaa Aleksis Kiven lyriikassa" maisematutkimuksen käsitteistön sovellettavuutta Kiven romanttisiin runoihin. Sari Salinin artikkelissa "Wilhelm Horsma vastaan kaikkitietävyys. Kaksi kertojaa Aapelin romaanissa Siunattu hulluus" lähestytään kotimaista modernismia narratologian välinein.

Jarkko Toikkasen puheenvuoro "Mediaalisuudet ja modaalisuudet" osallistuu kirjallisuudentutkimuksen uusia metodeja koskevaan keskusteluun. Projektit-esittelyssä on vuorossa Pirjo Hiidenmaan johtama Helsingin yliopiston tutkimushanke "Tiedonkerronta. Esitystavat ja tekijän läsnäolo kotimaisessa tietokirjallisuudessa”. Lehdessä on neljä kirja-arvostelua: Tuulikki Kurki arvioi Kukku Melkaksen ja Olli Löytyn toimittaman Toistemme viholliset? Kirjallisuus kohtaa sisällissodan (2018). Risto Turusen arvioitavana on Kai Häggmanin teos Kivelle perustettu. Suomen Kirjailijaliitto 1897-2017 (2017). Liisa Steinby paneutuu arviossaan Erich Auerbachin teokseen Maailmankirjallisuuden filologia (2018), ja lehden päättää Helmi Järviluoman arvio Sari Kivistön ja Sami Pihlströmin teoksesta Sivistyksen puolustus. Miksi akateemista elämää tarvitaan (2018).

Elina Arminen ja Anna Logrén 